\title{
PENGOLAHAN LIMBAH CAIR INDUSTRI BATIK SEBAGAI SALAH SATU PERCONTOHAN IPAL BATIK DI YOGYAKARTA
}

\author{
Lilin Indrayani \\ Balai Besar Kerajinan dan Batik Kementerian Perindustrian, RI \\ Email: indrayanililin@ gmail.com
}

\begin{abstract}
The World Craft Council (Word Craft Council) has awarded a title in Yogyakarta as the World Batik City. The increase in the batik industry in Yogyakarta in addition to providing a positive influence on economic improvement and community welfare also has a negative impact. One of the negative impacts is the emergence of large quantities of batik industry wastewater. Therefore, a pilot Waste Water Treatment (WWT) model is needed so that the batik industry in Yogyakarta City can have a technical reference for the waste treatment system. In this study, a sewage treatment system with several physical, chemical and biological treatments was introduced. So that it is expected that the batik industry wastewater that is processed through the pilot IPAL can meet the quality standards that have been determined in accordance with DIY Governor Decree No. 7 of 2016 concerning Waste Water Quality Standards for the Batik Industry. So that the liquid waste of the batik industry can be declared safe if it is discharged into the environment.
\end{abstract}

Keywords: wastewater of batik industry, WWT, environmental quality standards.

\section{PENDAHULUAN}

Dewan Kerajinan Dunia (Word Craft Council) Wilayah Asia Pasifik sebagai lembaga internasional yang berafiliasi dengan UNESCO memfokuskan pada peningkatan apresiasi terhadap berbagai kegiatan dan komunitas kerajinan di dunia, telah menganugrahkan sebuah predikat pada Yogyakarta sebagai Kota Batik Dunia pada 18 Oktober 2014 di Donyang, Tiongkok. Predikat kehormatan tersebut merupakan suatu hal yang membanggakan tidak hanya bagi Yogyakarta tetapi juga bagi bangsa Indonesia. Salah satu dari 7 (tujuh) kriteria penilaian yang dinyatakan baik adalah batik dianggap memiliki nilai ecofriendly (green value) yaitu adanya upaya pengembangan tradisi dari seni kerajinan yang mengarah pada kegiatan yang bersifat ramah lingkungan dan berkesinambungan.

Keberadaan industri batik di Kota Yogyakarta memiliki sejarah yang panjang, awalnya dimulai dari budaya kraton yang digunakan untuk mendukung kegiatan budaya kraton. Bersamaan dengan perkembangan dan besarnya minat masyarakat terhadap batik, sampai saat ini batik tidak hanya sebagai 'pakaryan dalem' tetapi sudah banyak dikenal oleh masyarakat luas baik dalam negeri maupun luar negeri. Oleh karena itu batik tidak hanya diproduksi khusus sebagai produk budaya tetapi sudah merupakan produk industri yang diproduksi dalam skala kecil sampai skala yang besar. Beberapa sentra industri batik di Kota Yogyakarta terpusat didaerah kraton, prawirotaman, mergangsan dan tirtodipuran menjadi 
industri penyangga bagi peningkatan perekonomian masyarakat Yogyakarta.

Namun demikian dengan peningkatan industri batik juga mengakibatkan dampak negatif yaitu masalah lingkungan. Permasalahan lingkungan saat ini yang dominan salah satunya adalah limbah cair berasal dari kegiatan proses pembuatan batik. Diperkirakan penggunaan air dalam proses pembuatan batik rata-rata kurang lebih $25-50 \mathrm{~m}^{2}$ permeter kain batik. Data kementerian perindustrian pada tahun 2017 memperlihatkan bahwa produksi batik di Indonesia rata-rata 500 juta meter pertahun, berarti 25 juta $^{3}$ air pertahun. Persediaan air untuk industri batik pertahun, setara dengan penyediaan kebutuhan air bersih untuk 2,500 rumah tangga (Balai Besar Kerajinan dan Batik, 2010).

Hampir 85 persen dari persediaan air bersih tersebut menjadi limbah cair batik dengan volume yang besar, warna yang pekat, dan berbau menyengat. Selain itu, limbah cair batik memiliki karateristik suhu, keasamam (pH), Biological Oxygen Demand (BOD), Chemical Oxygen Demand (COD), serta Total Suspended Solid (TSS) yang tinggi (Rohasliney dan Subki 2011). Suhu yang tinggi akan mengakibatkan kandungan oksigen terlarut dalam air menurun yang akan membunuh organisme dan limbah organik akan meningkatkan kadar nitrogen menjadi senyawa nitrat yang menyebabkan bau busuk (Sastrawijaya 2009).

Hal ini disebabkan oleh penggunaan bahan-bahan kimia dan zat warna dalam proses produksi batik. Bahan kimia yang digunakan dalam proses pembuatan batik antara lain: soda kaustik $(\mathrm{NaOH})$, soda abu $\left(\mathrm{Na}_{2} \mathrm{CO}_{3}\right)$, soda kue $\left(\mathrm{NaHCO}_{3}\right)$, asam sulfat $\left(\mathrm{H}_{2} \mathrm{SO} 4\right)$, sulfit, dan nitrit (Muljadi dan Muniarti 2013). Sedangkan zat warna yang digunakan antara lain: zat warna asam, zat warna basa, zat warna direk, zat warna reaktif, zat warna naftol, dan zat warna bejana. Selain itu komponen dari zat mordan (pengunci warna) yang digunakan dalam proses fiksasi pada pembuatan kain batik menggunakan beberapa unsur zat kimia, antara lain: tawas $\left(\mathrm{KAl}\left(\mathrm{SO}_{4}\right)_{2}\right)$, tunjung $\left(\mathrm{Fe}\left(\mathrm{SO}_{4}\right)\right)$, pijer/boraks, air kapur $\left(\mathrm{Ca}(\mathrm{OH})_{2}\right)$, kalsium karbonat $\left(\mathrm{CaCO}_{3}\right)$, kalsium hidroksida $\left(\mathrm{Ca}(\mathrm{OH})_{2}\right)$, asam sitrat $\left(\mathrm{C}_{6} \mathrm{H}_{8} \mathrm{O}_{7}\right)$, tembaga(II) sulfat $\left(\mathrm{Cu}_{2}\left(\mathrm{CH}_{3} \mathrm{COO}\right)_{4}\right)$, besi sulfat $\left(\mathrm{FeSO}_{4} .7 \mathrm{H}_{2} \mathrm{O}\right)$, dan kalium dikromat $\left(\mathrm{K}_{2} \mathrm{Cr}_{2} \mathrm{O}_{7}\right)$. Apabila air limbah dibuang ke lingkungan tanpa diolah terlebih dahulu, maka dapat menyebabkan pencemaran lingkungan terutama ekosistem perairan.

Beberapa permasalahan lain pada sentra industri batik yang berhubungan dengan permasalahan lingkungan adalah sebagai berikut(Indrayani, 2004):

a) Persepsi dan kepedulian para pelaku industri batik terhadap masalah limbah pada umumnya positif. Pengertian mereka cukup beragam, tetapi semuanya merasa bahwa tindakan membuang limbah ke lingkungan tanpa pengolahan limbah terdahulu akan merusak lingkungan dan mengancam kesehatan masyarakat sekitarnya. Rasa bersalah inilah yang diharapkan akan melahirkan keinginan untuk mengolah limbah yang mereka hasilkan. Disisi lain informasi tentang pengolahan limbah batik masih teramat terbatas. Oleh karena itu, belum ada suatu model pengolahan limbah khususnya untuk industri batik yang cukup populer dan mudah dimengerti dikalangan pelaku industri batik.

b) Pelaku industri batik masih memiliki pengertian yang benar antara mengadakan unit 
pengolahan limbah dengan pengoperasian unit pengolahan limbah. Hal ini terjadi khususnya pada industri kecil sedangkan pada industri yang relatif besar, hasil analisis terhadap kualitas air limbah tidak mewakili skala produksi limbah yang ada. Keadaan tersebut disebabkan sebagian besar industri batik yang berskala besar melimpahkan hampir lebih dari $50 \%$ produksinya kepada industri kecil. Hal ini berarti bahwa secara bersamaan industri besar membagi limbahnya kepada industri kecil yang jelas-jelas tidak mewakili instalasi pengolahan limbahnya.

c) Pelaku industri batik yang sebagian besar industri berskala kecil sangat peka mengenai dana pengolahan limbah. Informasi mengenai biaya untuk suatu pengolahan limbah masih sangat terbatas, sehingga banyak diantara mereka beranggapan bahwa pengelolaan limbah industri memerlukan biaya yang sangat tinggi. Hal tersebut tidak sepenuhnya benar dan tidak sepenuhnya salah. Sehingga masalah biaya merupakan trauma bagi industri batik berskala kecil.

d) Sejauh ini pemerintah daerah dinilai terlalu longgar dan tidak jelas dalam memberlakukan peraturan tentang pentingnya Instalasi Pengolahan Air Limbah (IPAL) bagi industri batik. Sampai sekarang banyak kalangan pemerhati lingkungan meragukan efektifitas IPAL yang dimiliki oleh industri besar, apalagi industri batik berskala kecil yang keberadaannya lebih banyak dibanding industri besar dan terkonsentrasi pada sentra-sentra industri, yang jelas-jelas belum memiliki IPAL.

Apabila dilihat dari karateristik limbah batik dan permasalahan limbah batik yang dialami oleh pelaku industri batik seperti tersebut diatas maka limbah batik dapat menimbulkan dampak kerusakan lingkungan dan kesehatan manusia dalam jangka waktu yang panjang dan kian meluas. Oleh karena itu dalam makalah ini disampaikan suatu penelitian tentang sistem pengolahan limbah dengan beberapa perlakuan secara fisika, kimia dan biologi. Seluruh proses tersebut bertujuan untuk menghilangkan kandungan padatan tersuspensi, koloid, dan bahan-bahan organik yang terlarut. Proses pengolahan yang termasuk pengolahan fisika antara lain: pengolahan dengan menggunakan screening, sedimentasi, filtrasi, sentrifugasi, dan flotasi. Proses pengolahan yang termasuk pengolahan kimia di antaranya: koagulasi, netralisasi, dan elektrokimia. Sehingga diharapkan limbah cair industri batik yang diolah melaluimodel percontohan IPAL batik ini dapat memenuhi baku mutu yang telah ditetapkan, sehingga aman apabila dibuang ke lingkungan.

\section{METODOLOGI}

Ruang lingkup penelitian ini adalah memberikan penjelasan contoh skema IPAL batik yang dapat menurunkan kadar pencemar pada limbah cair industri batik, agar limbah memenuhi baku mutu lingkungan yang sesuai dengan SK Gubernur DIY No 7 tahun 2016 tentang Baku Mutu Air Limbah Bagi Industri Batik, sehingga dapat dibuang ke lingkungan dapat dinyatakan aman. 


\section{Lokasi Penelitian}

Lokasi penelitian dilakukan pada salah satu industri batik di Yogyakarta yaitu ' $\mathbf{X}$ ' Batik yang memiliki IPAL batik.

\section{Bahan dan Alat}

a) Limbah cair industri batik yang diambil dari tahapan proses pengolahan batik pada ' $\mathbf{X}$ 'Batik.

b) Peralatan sampling limbah cair.

\section{Pengujian Sampel Limbah}

Pengujian sampel limbah cair industri batik dilakukan pada laboratorium lingkungan terakrediatasi Balai Besar Teknologi Keselamatan Lingkungan dan Pengendalian Penyakit (BTKLPP) Yogyakarta dengan parameter uji $\mathrm{pH}, \mathrm{BOD}, \mathrm{COD}$, TSS dan Minyak dan Lemak sesuai dengan SK Gubernur DIY No 7 tahun 2016 tentang Baku Mutu Air Limbah Bagi Industri Batik.

\section{Proses Pengolahan Limbah}

Tahapan proses pengolahan limbah yang dilakukan pada ' $\mathbf{X}$ ' Batik adalah sebagai berikut :

a) Bak penangkap malam (lilin)(pretreatment)

Sebelum diproses, seluruh limbah yang akan diolah dilewatkan pada penangkap lilin. Proses yang terjadi pada bak penangkap malam (lilin) adalah mendinginkan limbah yang masih panas (berasal dari proses penghilangan malam (lilin) atau proses pelorodan. Dalam bak ini limbah mengalami pendinginan dan mengakibatkan malam (lilin) yang terkandung dalam limbah akan mengapung. Selain itu bak ini berfungsi mencampur limbah dari proses pewarnaan dan pelepasan lilin (malam) atau proses pelorodan sehingga limbah yang masuk pada proses selanjutnya tidak fluktuatif.

b) Bak pengendapan atau sedimentasi (primary treatment) Proses sedimentasi merupakan unit pengolahan awal, prinsip kerjanya yaitu pengendapan dan stabilisasi bahan-bahan yang diendapkan, selain untuk mengendapkan dan menyaring partikel juga mereduksi beban organik yang terkandung dalam limbah, sehingga mengurangi beban untuk selanjutnya.

c) Kolam anaerob (secondary treatment)

Kolam anaerob disebut juga fixed bed reactor merupakan unit pengolahan kedua yang merupakan filter anaerob proses pengolahan limbah secara biologi pada kondisi anaerob. Media yang digunakan adalah botol plastik (botol kecap). Prinsip kerjanya memproses bahan - bahan yang tidak terendapkan dan bahan-bahan pelarut dengan cara mengontakkan dengan mikroorganisme yaitu bakteri anaerob. Penggunaan sistem filter anaerob biasanya kurang efektif tanpa unit tangki septik yang berfungsi untuk mengurangi beban organik (padatan terlarut) . Gabungan kedua unit proses ini disebut baffle anaerobic filter.

d) Kolam aerob (secondary treatment)

Kolam aerob merupakan bak penampung limbah cair dari hasil pengolahan yang berasal dari baffle anaerobic filter. Padakolam ini dipasang RBC sebagai filter aerob yang berfungsi mengontakkan bakteri 
aerob dengan udara dan limbah yang diolah.

e) Koagulasi dan Flokulasi (secondary treatment)

Koagulasi merupakan tingkat pengolahan kedua dengan cara mencampurkan bahan kimia berupa $\mathrm{Al}_{2}\left(\mathrm{SO}_{4}\right) \quad 18 \mathrm{H}_{2} \mathrm{O}$ (tawas) dan secara bersamaan dilakukan pengadukan secara tepat guna menstabilkan koloid dan solid tersuspensi yang halus, dan intinya massa partikel dan kemudian membentuk mikroflok. Sedangkan flokulasi merupakan pengadukan perlahan mikroflok sehingga terkumpul menjadi flok-flok yang dapat mengendap menjadi lumpur.

Adapun proses pengolahan limbah limbah lebih jelas pada skema blok pada gambar 1 dibawah ini:

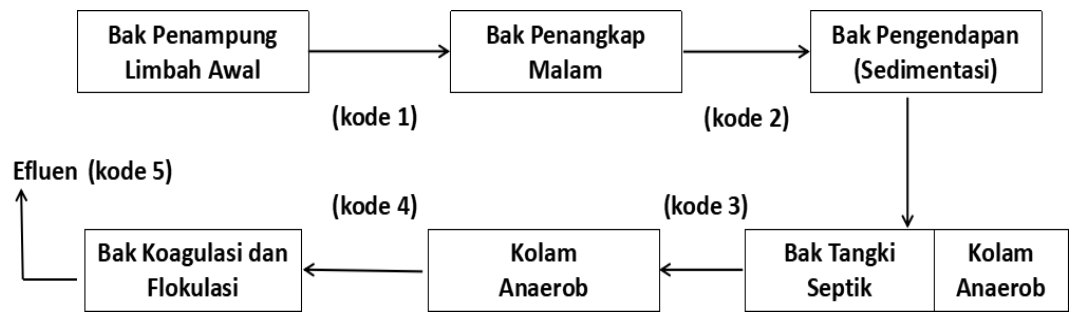

Gambar 1

Diagram Blok IPAL ' $X$ ’ Batik

\section{Pengambilan sampel}

Pengambilan sampel dilakukan pada tiap tahapan proses pengolahan limbah untuk mengetahui efektifitas penurunan kadar pencemar pada limbah cair industri batik. Adapun sampel yang diambil dari penelitian ini diberi kode sesuai tahapan pengolahan limbahnya sebagai berikut:

Tabel 1. Kode limbah pada tahapan proses pengolahan limbah

\begin{tabular}{|c|l|}
\hline Limbah & \multicolumn{1}{|c|}{ Perlakuan Limbah } \\
\hline Kode 1 & $\begin{array}{l}\text { Limbah cair sebelum } \\
\text { pengolahan limbah }\end{array}$ \\
\hline Kode 2 & $\begin{array}{l}\text { Limbah cair setelah bak } \\
\text { penangkap malam }\end{array}$ \\
Kode 3 & $\begin{array}{l}\text { Limbah cair setelah tangki } \\
\text { septik dan proses anaerob }\end{array}$ \\
\hline Kode 4 & $\begin{array}{l}\text { Limbah cair setelah proses } \\
\text { anaerob }\end{array}$ \\
\hline Kode 5 & $\begin{array}{l}\text { Limbah cair setelah proses } \\
\text { koagulasi dan flokulasi }\end{array}$ \\
\hline
\end{tabular}

\section{Rancangan Penelitian}

Dalam penelitian ini menggunakan Rancangan Acak Lengkap (RAL) 1 faktor. Persamaan RAL tersebut adalah sebagai berikut:

$$
\mathrm{Y}_{\mathrm{ij}}=\mu_{\mathrm{ij}}+\tau_{\mathrm{ij}}+\varepsilon_{\mathrm{ij}}
$$

Dengan keterangan,

$Y_{i j}$,respon ij diamati pada parameter kei dengan ulangan ke-j

$\mu_{\mathrm{ij}, \text { rataan umum }}$

$\mathrm{T}_{\mathrm{ij}}$, parameter ke-i

$\sum_{\mathrm{ij}}$, galat pada parameter ke-i dengan ulangan ke-j

\section{HASIL DAN PEMBAHASAN}

\subsection{Temuan dan kajian atas temuan yang diperoleh \\ 3.1.1 Temuan}

Unit pengoperasian dan proses-proses dalam pengolahan limbah cair dikelompokkan untuk menunjukkan tahapan proses pengolahan. Istilah pengolahan awal (pretreatment) adalah perlakuan tertentu sebelum masuk dalam skema IPAL, pengolahan primer atau 
primary treatment menunjuk pengolahan secara fisika, sedangkan pengolahan sekunder (secondary treatment) menunjuk pada proses pengolahan secara biologi dan kimia. Sedangkan pengolahan lanjutan (tertiary treatment) menunjuk pada kombinasi antara ketiganya atau penambahan proses pengolahan tahap akhir apabila limbah pada tahap akhir belum memenuhi baku mutu.

\section{A. Pengolahan awal(pretreatment)}

Pengolahan awal limbah cair didefinisikan sebagai penghilangan unsur pada limbah cair yang berukuran besar yang dapat menyebabkan gangguan pada operasional atau pemeliharaan. Salah satu contoh dalam proses ini adalah proses penyaringan (screening). Proses penyaringan biasa menggunakan kisi kisi penyaring (bar screen) yang terdiri dari bar paralel yang berjarak $40 \mathrm{~mm}-80 \mathrm{~mm}$ tergantung dari ukuran padatan dari limbah tersebut. Dalam limbah cair batik proses penyaringan pada tahap awal ini berfungsi untuk menangkap kandungan minyak dan lemak yang berasal dari malam (lilin) batik. Minyak dan lemak tidak dapat larut dalam air sehingga mengapung dipermukaan air limbah, apabila masuk dalam alat pengolahan limbah maka akan menyebabkan penyumbatan dan merusak peralatan pengolahan selanjutnya.

\section{B. Pengolahan primer (primary treatment) \\ Dalam pengolahan primer} sebagian besar padatan tersuspensi dan bahan organik dihilangkan dari limbah cair. Penghilangan ini biasanya dilakukan dengan secara fisika dengan proses pengendapan (sedimentasi). Efluen dari pengolahan primer umumnya masih mengandung bahan organik dalam jumlah besar dan BOD masih relatif tinggi. Fungsi pengolahan primer tetap ada sebagai langkah pendahuluan terhadap pengolahan sekunder. Limbah cair yang belum diolah mengandung bahan yang akan mengendap atau mengapung pada permukaan ketika mengalir dengan kecepatan rendah. Saluran limbah cair dirancang agar aliran limbah dapat mengalir cepat sedangkan padatannya mengalir pada kecepatan lebih lambat, sehingga bahan organik padatan mengalir pada kecepatan yang lebih lambat, dan akan mengumpul didasar saluran dan selanjutnya dibuang. Bak pengendapan (sedimentasi) dapat mengurangi kecepatan limbah cair menjadi jauh dibawah kecepatan disaluran limbah pengumpul.

Proses pengendapan (sedimentasi) menghilangkan kira-kira $55 \%$ dari padatan tersuspensi dan lebih kurang $35 \%$ dari keseluruhan BOD pada limbah cair. Pengurangan BOD adalah sederhana saja karena kenyataannya sebagian besar padatan tersuspensinya berbentuk organik, sehingga dapat terurai secara biologis. Menurut pada limbah batik pada proses ini umummnya memiliki konsentrasi padatan tersuspensi berkisar dalam skala ribuan sampai $200 \mathrm{mg} / \mathrm{l}$ dan BOD dari skala ribuan sampai $250 \mathrm{mg} / \mathrm{l}$.

\section{Pengolahan sekunder (secondary treatment)}

Pengolahan sekunder pada prinsipnya bertujuan untuk menghilangkan bahan organik yang terurai serta padatan tersuspensi. Pengolahan sekunder dapat merupakan kombinasi dari pengolahan secara kimia maupun secara biologi. Pada proses kimia pada prinsipnya menambahkan bahan kimia untuk mempermudah dan mempercepat proses pengolahan limbah, salah satu proses kimia tersebut adalah proses koagulasi dan flokulasi. Pusat Teknologi Limbah (2000) telah melakukan pengujian laboratorium terhadap nilai kekeruhan pada sampel 
limbah dibeberapa sentra industri batik di Yogyakarta dengan metode jar-test untuk pengolahan kimiawi secara koagulasi. Hasil pengujian tersebut membandingkan efektifitas bahan koagulan ferri sulphat $\mathrm{Fe}_{2}\left(\mathrm{SO}_{4}\right)$ atau tunjungdan $\mathrm{KAl}\left(\mathrm{SO}_{4}\right)_{2} \cdot 12 \mathrm{H}_{2} \mathrm{O}$ (tawas) diperoleh hasil bahwa tawas lebih efektif dan murah dalam pengolahan limbah batik.

Pada proses biologi dikenal dua sistem pengolahan yaitu sistem pengolahan secara aerob dan anaerob. Proses aerob adalah suatu proses memasukkan udara ke dalam air limbah yang akan diolah. Penyediaan udara ini bertujuan untuk meningkatkan kenyamanan dan kondisi sehingga bakteri pengurai bahan organik dapat tumbuh dan berkembang biak dengan baik. Hal ini membantu terjadinya pengendapan ke dalam bak aerasi dan menyebabkan penambahan oksigen kedalam sel. Sedangkan proses anaerob adalah proses yang tidak memerlukan pasokan oksigen kedalam limbah yang diolah. Menurut Sumantri (2000) pengolahan limbah cair industri batik dengan menggunakan proses anaerob dengan bentuk reaktor (anaerob baffed reactor) mempunyai efektifitas yang tinggi bila digunakan didaerah tropis (mikroorganisme mesofilik) dan memberi kontak yang lebih baik antara mikroorganisme dan air limbah (upflow dan down flow).Penelitian Tjandra dan Hasibuan (1998) tentang penggunaan kombinasi proses aerob dan anaerob dalam pengolahan limbah industri tekstil dapat menurunkan kualitas warna, dan mengurangi lumpur buangan dan membatasi zat kimia pada proses pengolahan limbah. Pengujian laboratorium terhadap sampel limbah cair menunjukkan bahwa kombinasi kedua sistem tersebut tidak hanya menurunkan nilai BOD dan COD sampai 60-75\% tetapi juga kadar logam berat yang terdapat dalam limbah.
Penggunaan sifat alami mikroorganisme dan teknik bioteknologi merupakan cara pengolahan limbah secara biologis dengan memakai filter aerob. Salah satu jenis filter aerob adalah Rotating Biological Contractor (RBC). Eleminasi bahan biologis dapat dilakukan dengan sistem biofilm mikroba pengurai yang dilekatkan pada media RBC, dengan tekanan yang besarnya sama dengan parsial dari oksigen. RBC sangat tahan terhadap fluktuasi beban yang berubah ubah mudah dan biayanya rendah (Hirata dan Meutia). RBC merupakan salah satu inovasi teknologi dalam bioteknologi pengolahan air limbah yang mempunyai banyak kelebihan antara lain:

1) Konservasi energi.

2) Keterbatasan lahan untuk stabilitas terhadap beban limbah yang spontan (shocks load).

3) Kinerja proses sistem yang tinggi.

4) Pengoperasian dan perawatan relatif murah, mudah dan sederhana (Soeratno, 1992)

5) Harsono dan Tarigan (1994), melaporkan bahwa RBC mampu memperkecil konsentrasi NH4- 50 $\mathrm{mg} / \mathrm{l}$ menjadi $0.054 \mathrm{mg} / \mathrm{l}$ pada waktu detensi 7 jam dan efisiensi penyisihan $99,90 \%$.

6) RBC ini telah dicoba untuk mengolah air limbah dari zat warna sintetis yang mengandung organik tinggi dengan beban yang berfluktuatif dan berhasil baik (Tarigan dan Meutia 1997).

D. Pengolahan lanjutan (tertiary

Pengolahan limbah pada tahap ini merupakan pengolahan pada ahap akhir. Pada tahap ini efluen pada tahap ini diukur dengan baku mutu limbah untuk industri batik. Apabila belum memenuhi baku mutu perlu dilakukan proses pengolahan lanjutan, tetapi bila sudah 
memenuhi air buangan dapat dikatakan aman untuk dibuang ke perairan umum. Contoh pengolahan lanjutan antara lain adalah metode lahan basah buatan, penggunaan penyerap dan penjernih (absorbent).
Dari hasil penelitian ini diperoleh hasil pengujian laboratorium terhadap sampel limbah cair industri batik dari 5 (lima) tahapan proses pengolahan limbah yang diwakili dengan kode 1 sampai dengan kode 5, sesuai dengan tabel dibawah ini:

Tabel 2. Hasil Analisis Kualitas dan Kuantitas Limbah Cair Industri Batik

\begin{tabular}{|c|c|c|c|c|c|c|}
\hline \multirow{2}{*}{ Parameter } & \multicolumn{5}{|c|}{ Rerata (mg/l) } & $\begin{array}{c}\text { Baku Mutu* } \\
(\mathrm{mg} / \mathrm{l})\end{array}$ \\
\cline { 2 - 7 } BOD & 1 & 2 & 3 & 4 & 5 & 50 \\
\hline COD & 1470.036 & 408.750 & 771.333 & 156.000 & 45.439 & 100 \\
\hline $\begin{array}{c}\text { TSS } \\
\text { Linyak \& }\end{array}$ & 3124.251 & 699.382 & 1979.212 & 211.000 & 94.136 & 200 \\
\hline pH & 1485.810 & 72.125 & 135.250 & 103.000 & 113.990 & 5 \\
\hline
\end{tabular}

* SK Gubernur DIY No 7 tahun 2016 tentang Baku Mutu Air Limbah Bagi Industri Batik

E. Kualitas dan kuantitas limbah cair sebelum dilakukan pengolahan (kode 1)

Dari tabel 2 diatas memperlihatkan bahwa padasemua parameter pada sampel kode 1 menunjukkan nilai yang melebihi baku mutu lingkungan. Limbah cair tersebut berasal dari limbah campuran dari proses pewarnaan, pencucian, pembilasan maupun dari proses pelepasan malam (pelorodan) dikumpulkan ke dalam satu bak penampung. Limbah ini berwarna sangat pekat dan sampel yang diambil dari bak penampung ini mewakili keadaan limbah tanpa perlakuan dan sebelum dilakukan proses pengolahan limbah (influen).

F. Hasil pengolahan limbah melalui bak penangkap malam (kode 2)

Pada proses pendahuluan (pretreatment), limbah yang berasal dari bak penampung dialirkan ke bak penangkap lilin (malam). Proses pengolahan limbah cair yang terjadi pada bak penangkap lilin adalah proses pengendapan (sedimentasi). Pada saat limbah didinginkan pada proses ini secara bersamaan terjadi pengendapan.
Benda-benda yang padat yang mempunyai nilai bobot jenis yang lebih besar dari bobot jenis air dengan sendirinya akan mengendap. Sedangkan khusus untuk kandungan minyak dan lemak akan mengapung. Proses pengendapan terjadi relatif lebih efisien pada kondisi limbah dengan suhu yang tinggi. Semakin tinggi suhu semakin cepat taraf sedimentasi disebabkan sifat nelekat benda yang menurun(Mahid, 1998).

Dari tabel 2 diatas memperlihatkan bahwa semua parameter masih memiliki nilai yang melebihi baku mutu lingkungan.Hasil akhir proses pengendapan(sedimentasi) beberapa padatan mengendap sedangkan sebagian minyak dan lemak masih mengapung.Limbah cair pada bagian tengah memiliki warna yang relatif lebih jernih dibanding limbah yang berasal dari bak penampung (kode1).

G. Hasil pengolahan limbah melalui tangki septik dan kolam anaerob (kode 3)

Limbah akhir dari pengolahan bak-bak pendingin dialirkan ke unit 
pengolahan selanjutnya yaitu bak berikutnya yaitu bak baffle anaerobic reaktor. Sistem pengolahan ini terdiri dari tangki septik dan kolam anaerob. Kedua bagian ini merupakan konstruksi bangunan yang terbuat dari berpasangan secara terpisah tetapi berhubungan satu sama lain. Sebuah tangki septik merupakan tangki pengumpul anti bocor dimana limbah dialirkan oleh saluran air dengan siraman yang kuat. Tangki septik tidak menghilangkan limbah, hanya membantu memisahkan dan menghancurkan benda benda padat pada limbah cair. Pada tangki septik terjadi proses pengendapan(sedimentasi). Pengendapan bahan padat yang mengendap akan membentuk lumpur, lalu limbah cair akan dialirkan ke kolam anaerob dimana bakteri memegang peranan dalam pengolahan selanjutnya.

Kolam anaerob tidak mengandung oksigen terlarut. Proses ini tergantung pada fermentasi lumpur didasar kolam. Kondisi ini akan menimbulkan bau pada kondisi tertentu, tetapi sangat efisien untuk menghancurkan limbah organik. Kolam anaerob dipenuhi oleh botol plastik (botol kecap bekas) sebagai media untuk pertumbuhan bakteri pengurai zat pencemar limbah. Penggunaan plastik dalam media ini bermaksud agar media tersebut tahan lama dan tidak perlu diganti sepanjang umur IPAL. Pada pengolahan secara biologis ini, bahan-bahan organik mula-mula dikonversi oleh sekelompok bakteri penghasil asam yaitu bakteri yang mampu mengubah karbondioksida, nitrogen dan asam-asam organik. Secara bersamaan sekelompok bakteri lain yang mempunyai kemampuan fermentasi metana menguraikan asam serta produk-produk lain dari kelompok pertama menjadi gas metana dan alkali. Produksi akhir yang diperoleh dari dekomposisi organik adalah air.
Limbah akhir dari proses ini ditampung dalam sebuah bak lalu diambil sampel untuk pengecekan kualitas dan kuantitas limbah hasil pengolahan setelah proses pengendapan dan kolam anaerob.Dari tabel 2 memperlihatkan bahwa rataan nilai BOD, COD minyak dan lemak masih tinggi mengalami penurunan nilai dibanding dengan pengolahan sebelumnya dan masih melebihi nilai baku mutu sedangkan untuk nilai TSS dan $\mathrm{pH}$ sudah memenuhi nilai baku mutu.

H. Hasil pengolahan sistem aerob (kode 4)

Pada pengolahan dengan sistem aerob menggunakan Rotating Biological Constractor (RBC) yang berfungsi sebagai aerator untuk proses aerasi. Peralatan ini mempunyai sebuah poros putar yang dikelilingi oleh cakram-cakram plastik yang digunakan sebagai media untuk tumbuhnya bakteri aerob. RBC diputar untuk mengalirkan air limbah secara tegak lurus ke poros ketika limbah mengalir ke tangki satu ke tangki yang lain. Untuk menampung limbah cair yang diolah digunakan bak beton. Media tersebut berputar kira kira 1,5 rpm sedangkan lebih kurang sekitar $40 \%$ permukaan terendam limbah didalam air. Ketika drum diputar media mengambil lapisan tipis limbah cair yang mengalir. Bakteri yang hidup menggunakan bahan organik yang berasal dari limbah cair dan oksigen yang terlarut dari udara sebagai makanan. Ketika bakteri yang melekat mengalir melalui limbah cair, bakteri dapat mengurai kadar pencemar dalam limbah tersebut.

Dari tabel 2 menunjukkan bahwa RBC menghasilkan penurunan nilai BOD, COD, minyak dan lemak yang cukup signifikan sehingga nilai BOD dan COD sudah memenuhi baku mutu. Namun nilai minyak dan lemak walaupun mengalami 
penurunan masih melebihi baku mutu. Sedangkan untuk nilai pH dan TSS sudah dapat dikatakan aman untuk lingkungan.

I. Hasil pengolahan limbah melalui proses koagulasi dan flokulasi (kode 5)

Pada proses ini penyesuaian $\mathrm{pH}$ sangat perlu untuk mendapatkan tingkat pengentalan yang tinggi. Setelah benda-benda padat yang mengambang terjadi pengikatan oleh bahan koagulan, maka selanjutnya terjadi proses pendepanan (sedimentasi). Pada proses ini terjadi endapan lumpur, sedangkan limbah cair semakin jernih. Pada proses pemberian tawas, secara bersamaan dilakukan pengadukan agar pencampuran bahan koagulan dengan limbah cair terjadi secara homogen dan merupakan upaya untuk memasukkan oksigen dalam limbah.

Dari tabel 2 menunjukkan hasil bahwa parameter BOD dan COD mencapai nilai aman sedangkan nilai minyak dan lemak masih melebihi baku mutu lingkungan. Nilai $\mathrm{pH}$ dan TSS tidak melebihi baku mutu dan sudah dapat dikatakan aman untuk lingkungan.

\subsubsection{Kajian}

Perhitungan tingkat efesiensi dilakukan untuk menunjukkan bahwa tiap-tiap proses pengolahan limbah memiliki pengaruh terhadap prosentase penurunan kadar pencemar. Adapun pengaruh tersebut secara lebih rinci dijelaskan pada tabel 3 dibawah ini:

Tabel 3. Perhitungan tingkat efektifitas tiap tahapan pengolahan limbah

\begin{tabular}{|c|c|c|c|c|c|}
\hline \multirow{2}{*}{$\begin{array}{c}\text { Kode } \\
\text { Limba } \\
\mathrm{h}\end{array}$} & BOD & COD & TSS & $\begin{array}{c}\text { Minyak } \\
\text { dan } \\
\text { Lemak }\end{array}$ & $\mathrm{pH}$ \\
\hline 1 & & & & & \\
\hline 2 & 72.19 & 92.33 & 81.35 & 74.67 & 10.83 \\
\hline 3 & 88.70 & -182.9 & -87.52 & -174.952 & -8.9 \\
\hline 4 & 40.88 & 38.81 & 23.84 & 61.53 & 17.31 \\
\hline 5 & 24.24 & 34.42 & -10.67 & 38.56 & 3.66 \\
\hline
\end{tabular}

A. Pengaruh tahapan pengolahan limbah terhadap parameter BOD

Hasil perhitungan pada tabel 3 memperlihatkan bahwa tingkat efektifitas pada setiap tahapan pengolahan limbah mengalami penurunan nilai BOD. Penurunan nilai BOD paling signifikan adalah pada tahap pertama yaitu proses sedimentasimenyusul proses anaerob dan anaerob. Pada proses anaerob reaksi reaksi tidak memungkinkan adanya penambahan oksigen, sehingga tidak berpengaruh terhadap nilai BOD. Didalam filter anaerob limbah dikontakan dengan bakteri yang bekerja untuk menguraikan senyawa-senyawa organik (misalnya senyawa azo) menjadi senyawa-senyawa yang lebih sederhana. Rantai azo mempunyai gugus kromofor yang mampu menyerap warna pada gelombang 400-700 nm. Pada filter anaerob bakteri pengurai memecah menjadi senyawa aromatik yang tidak dapat menyerap cahaya. Proses ini disebut proses pendegradasian warna karena terjadi pelepasan ikatan azo.

Pada tabel 3 juga menunjukkan bahwa perbedaan nilai BOD secara signifikan juga dipengaruhi oleh pengolahan secara aerob dan proses koagulasi dan flokulasi. Penurunan BOD pada tahap ketiga yaitu dengan menggunakan filter anaerob disebabkan adanya penambahan oksigen dari luar melalui alat RBC yang berfungsi sebagai aerator. Pengolahan secara aerob adalah pengolahan limbah dengan kondisi terdapatnya oksigen ditempat bakteri yang akan menguraikan air limbah. Senyawa-senyawa organik yang terdapat dalam air limbah dapat dipecah dengan bakteri aerob menjadi senyawa senyawa yang tidak mencemari lingkungan. Pada pengolahan limbah cair batik dengan menggunakan tawas sebagai bahan koagulan dan polimer pada proses flokulasi juga mempengaruhi penurunan nilai BOD. Hal ini kemungkinan pada 
saat proses koagulasi dan flokulasi dilakukan pengadukan sehingga pada saat bersamaan memungkinkan oksigen dari luar masuk ke dalam limbah dan berikatan dengan senyawa-senyawa yang ada didalamnya.

B. Pengaruh tahapan pengolahan limbah terhadap parameter COD

Hasil perhitungan pada tabel 3 memperlihakan bahwa pengolahan limbah dengan filter anaerob pada perlakuan 3 dan penggunaan bahan koagulasi dan flokulasi pada perlakuan 5 terjadi perbedaan ti, hal ini dikarenakan adanya penambahan tawas untuk mengendapakan lumpur dalam proses koagulasi dalam waktu bersamaan menambah beban kimia dalam limbah. Sedangkan pada proses sedimentasi dan pengolahan pada filter anaerob terjadi perbedaan secara signifikan. Hal ini terjadi karena tidak tersedianya oksigen yang cukup untuk mengoksidasi zat zat kimiawi dalam limbah pada kedua perlakuan dalam pengolahan tersebut. Penurunan nilai COD secara signifikan terlihat pada proses pengolahan dengan kolam aerob. Bakteri aerob bekerja sangat aktif untuk menguraikan bahan-bahan kimia yang terkandung didalam limbah cair tersebut.

C. Pengaruh tahapan pengolahan limbah terhadap parameter TSS

Hasil analisis pada nilai TSS terlihat pada tabel 3 hanya terjadi signifikan pada proses sedimentasi. Sedangkan untuk perlakuan 3,4, 5 tidak terjadi penurunan TSS secara signifikan. Hal itu disebabkan karena karena limbah yang baru dari proses sedimentasi masuk ke dalam proses-proses selanjutnya bercampur dengan endapan lumpur dari proses sebelumnya.
D. Pengaruh tahapan pengolahan limbah terhadap parameter $\mathrm{pH}$

Dari tabel 2 menunjukkan bahwa setiap perlakuan tidak mempengaruhi kenaikan dan penurunan nilai $\mathrm{pH}$. Dari keseluruhan perlakuan memang tidak menunjukkan perlakuan yang yang dapat mempengaruhi nilai $\mathrm{pH}$. Dari kesuluruhan nilai parameter $\mathrm{pH}$ pada tabel 3 semua nilai tidak melebihi baku mutu lingkungan.

E. Pengaruh tahapan pengolahan limbah terhadap parameter minyak dan lemak

Dari tabel 3 menunjukkan bahwa setiap proses pengolahan limbah dapat menurunkan nilai minyak dan lemak. Akan tetapi nilai minyak dan lemak masihmelebihi ambang batas baku mutu lingkungan pada pengolahan pada tahap akhir. Hal ini disebabkan belum adanya perlakuan khusus untuk limbah yang berasal dari proses pelorodan.

\section{SIMPULAN DAN SARAN}

\subsection{Kesimpulan}

Dari hasil penelitian ini dapat disimpulkan bahwa skema IPAL pada ' $\mathrm{X}$ ' Batik dapat menurunkan kadar pencemar pada industri batik. Nilai BOD, COD, TSS dan $\mathrm{pH}$ tidak melebihi ambang batas baku mutu lingkungan, sedangkan untuk nilai parameter minyak dan lemak belum memenuhi baku mutu sehingga perlu penanganan limbah pelorodan sebelum masuk skema IPAL tersebut.

\subsection{Saran}

Perlu adanya perlakuan pemisahan antara limbah cair dari proses pewarnaan dengan limbah cair yang berasal dari proses pelepasan malam (pelorodan) untuk mempermudah penyaringan minyak dan lemak pada tahap awal sebelum melalui skema IPAL. Hal ini 
berguna untuk mengurangi beban minyak dan lemak pada proses selanjutnya. Perlu dilakukan bak pemisah lumpur yang sesuai dengan kapasitas lumpur yang terbentuk pada proses koagulasi dan flokulasi. Hal ini perlu dilakukan agar terjadi pemisahan antara lumpur dengan limbah cair yang telah diolah, sehingga limbah akhir aman dibuang ke lingkungan.

\section{DAFTAR PUSTAKA}

Balai Besar Kerajinan dan Batik, 2010,Pengolahan Limbah industri Batik, Yogyakarta.

Clean Batik Initiative, 2010. Pedoman Produksi Bersih untuk Industri Batik.

Indrayani, Lilin, 2004. Pengolahan Limbah Cair Industri Batik Yogyakarta , Tesis Yogyakarta, PSL-IPB. Bogor

Maeda, S., 1990, Accumulation And Detoxification of Toxic Metal Element by Algae, SPB AcademicPublishing, Japan.

Mahida, U.N.1993. Pencemaran Air dan Pemanfaatan Limbah Industri, PT Rajagrasindo Persada. Jakarta

Meutia, A.A dan T. Suryono. 1997. Pengelolaan Air Limbah Pabrik Kosmetik dengan Sistem Reaktor Terpadu.

Muljadi, Muniarti.2013. Pengolahan limbah batik cetak dengan menggunakan metode filtrasi-elektrolisis untuk menentukan efisiensi penurunan parameter COD, BOD dan logam berat $(\mathrm{Cr})$ setelah perlakuan fisika kimia. Ekuilibrium.12(1): 27-36.
Novita, D. 2001, Degradasi Nitronaptol Limbah Cair Batik Menggunakan Mikroorganisme Tanah dan Air Dengan didahului oleh Perlakuan Koagulasi, Skripsi STTL, Yogyakarta.

Peraturan Menteri Lingkungan Hidup No. 5 Tahun 2014 tentang baku mutu air limbah.

Rohasliney H, Subki NS.2011. A Preliminary Study on Batik Effluent in Kelantan State: A Water Quality Perspectiv. International Conference on Chemical, Biological, and Environment Science; 2011 Des; Bangkok, Thailand. Bangkok (TH): 274-276

Sastrawijaya, A.T. 1991, Pencemaran Lingkungan. Penerbit Rineka Cipta, Surabaya.

Wardhana, W. A., 2004, Dampak Pencemaran Lingkungan, Yogyakarta : Penerbit Andi 